\title{
DAMPAK PROGRAM PLBK \\ (PENATAAN LINGKUNGAN BERBASIS KOMUNITAS) YANG DIDUKUNG OLEH UNIT PENGELOLA KEUANGAN PNPM MANDIRI TERHADAP PERILAKU MASYARAKAT DAN TINGKAT KESEJAHTERAANNYA
}

\author{
Muhammad Awaluddin Ardiansyah \\ Department of Economics, Faculty of Economics Andi Djemma University, \\ Jl. Sultan Hasanuddin No.13, Palopo, Sulawesi Selatan, Indonesia \\ Email Korespondensi: muh.awalardiansyah@gmail.com
}

Naskah Diterima: Juni 2016; Disetujui: September 2016

\begin{abstract}
This study aims to determine the effect of Community-Based Neighborhood Arrangement (PLBK) program from PNPM Mandiri to the behavior and welfare level of the community in Kecamatan Lalabata, Soppeng regency of South Sulawesi. This PLBK program includes the establishment of government schools, the construction of hospitals and the provision of the Financial Management Unit (UPK). This research uses mixed methods method. Quantitative methods use simple linear regression analysis while qualitative methods use indepth interviews with Leiden Ethnosystems. The results of this study indicate that the most influential variable in increasing the economic level of the community is the interest rate provided by the UPK. While in the program of behavior change and changes in the level of community welfare, the establishment of free schools and the construction of hospitals is expected to encourage people to improve their education level and quality of health. The results of this study indicate that the function of IMM (Integrated Microfinance Management) is a solution to the problem of poverty and in rural communities.
\end{abstract}

Keywords: Community-Based Neighborhood Arrangement (PLBK), National Program for Community Empowerment (PNPM), integrated microfinance management

JEL Classifications: D1, D6, E6.

Abstrak: Penelitian ini bertujuan untuk mengetahui pengaruh program Penataan Lingkungan Berbasis Komunitas (PLBK) dari PNPM Mandiri terhadap perilaku dan tingkat kesejahteraan masyarakat di Kecamatan Lalabata, Kabupaten Soppeng Sulawesi Selatan. Program PLBK ini meliputi pendirian sekolah pemerintah, pembangunan rumah sakit dan penyediaan Unit Pengelola Keuangan (UPK). Penelitian ini menggunakan metode mixed methods. Metode kuantitatif menggunakan analisis regresi linier sederhana sedangkan metode kualitatif menggunakan wawancara mendalam dengan Leiden Ethnosystems. Hasil dari penelitian ini menunjukkan bahwa variabel yang paling berpengaruh dalam peningkatan tingkat perekonomian masyarakat adalah tingkat suku bunga yang diberikan oleh UPK. Sedangkan di dalam program perubahan perilaku dan perubahan tingkat kesejahteraan masyarakat, pendirian sekolah gratis dan pembangunan rumah sakit diharapkan mampu mendorong masyarakat untuk memperbaiki tingkat pendidikan dan kualitas kesehatan mereka. Hasil dari penelitian ini menunjukkan bahwa fungsi IMM (Integrated Microfinance Management) merupakan solusi untuk permasalahan kemiskinandan di dalam masyarakat pedesaan.

Kata kunci: Penataan Lingkungan Berbasis Komunitas (PLBK), Program Nasional Pemberdayaan Masyarakat (PNPM), manajemen keuangan mikro terpadu

Kasifikasi JEL: D1, D6, E6 


\section{PENDAHULUAN}

Pembangunan bidang pendidikan dan kesehatan merupakan dua pilar untuk membentuk modal manusia (human capital) dalam pembangunan ekonomi yang tidak lain merupakan investasi dalam jangka panjang. Tercapainya tujuan pembangunan bidang pendidikan dan kesehatan, pada gilirannya dapat meningkatkan kualitas dan produktivitas penduduk, dimana pertumbuhan produktivitas penduduk tersebut merupakan motor penggerak (engine of growth) pertumbuhan ekonomi dan kesejahteraan penduduk itu sendiri. Melalui investasi pendidikan akan mampu meningkatkan kualitas sumberdaya manusia yang diperlihatkan oleh meningkatnya pengetahuan dan keterampilan sehingga mendorong peningkatan produktivitas kerja penduduk. Pada akhirnya penduduk akan memiliki produktivitas yang tinggi sehingga memperoleh kesejahteraan yang lebih baik dan terhindar dari kemiskinan.

Perbaikan tingkat kesehatan pada dasarnya merupakan suatu investasi sumber daya manusia untuk mencapai masyarakat yang sejahtera (welfare society). Tingkat kesehatan masyarakat yang ditunjukkan oleh Angka Harapan Hidup $(\mathrm{AHH})$ sebagai indikatornya akan sangat berpengaruh terhadap tingkat kesejahteraan masyarakat dan memiliki keterkaitan yang erat dengan kemiskinan. Sementara itu, tingkat kemiskinan akan terkait dengan tingkat kesejahteraan. Oleh karena kesehatan merupakan faktor utama dalam upaya peningkatan kesejahteraan masyarakat, maka kesehatan selalu menjadi perhatian utama pemerintah sebagai penyelenggara pelayanan publik. Pemerintah harus dapat menjamin hak masyarakat untuk sehat (right for health) dengan memberikan pelayanan kesehatan secara adil, merata, memadai, terjangkau, dan berkualitas.

Sama halnya dengan kesehatan, pendidikan merupakan suatu bentuk investasi sumber daya manusia. Tingkat pendidikan juga berpengaruh terhadap tingkat kemiskinan karena pendidikan merupakan salah satu komponen yang tekankan dalam penyebab lingkaran kemiskinan. Salah satu cara untuk mengatasinya adalah melalui pendidikan dasar wajib, yang oleh pemerintah diterjemahkan dalam program wajib belajar sembilan tahun.

Rendahnya tingkat kesehatan dan pendidikan pada rumah tangga miskin merupakan tantangan utama yang harus dihadapi Indonesia dalam rangka penanggulangan kemiskinan. Masih tingginya angka mortalitas balita serta rendahnya tingkat penyelesaian pendidikan dasar dan menengah pertama anak-anak dalam rumah tangga miskin, merupakan isu-isu strategis yang sangat berpotensi menghambat upaya penanggulangan kemiskinan di Indonesia. Sebagai ilustrasi awal dari angka kematian anak pada tahun 2000 menurut WHO masih mencapai 10,6 juta anak per tahun, dan dari jumlah itu Indonesia "menyumbang" 280.000 nyawa anak, serta bersama 41 negara lain memberi kontribusi sebesar 5 juta jiwa. Selain itu, berdasarkan data Badan Standar Nasional Pendidikan (BSNP) Kemdiknas (2012), tingkat kelulusan siswa SMP di Sulawesi Selatan pada 2012 mencapai 99,42\% (rangking 21 nasional) dan MTs 99,27\% (rangking 26). Kelulusan siswa tingkat SMA jurusan IPA 99,75\% (rangking 23) dan SMA jurusan IPS 98,81\% (rangking 25 nasional). Tingkat kelulusan siswa MA (Madrasah) jurusan IPA 99,78\% (rangking 17), MA jurusan IPS 98,21\% (rangking 18). Tingkat kelulusan pada jenjang SMK 98,59\% (rangking 26) dari 33 provinsi di Indonesia. Tanpa disertai upaya peningkatan kesehatan dan pendidikan, terutama kepada anak-anak generasi mendatang yang hidup dalam setiap rumahtangga miskin, upaya untuk mengurangi angka kemiskinan di Indonesia akan sulit dilakukan.

Satu ciri menonjol masyarakat miskin adalah tidak adanya akses kepada sarana dan prasarana dasar lingkungan yang ditandai dengan kualitas perumahan dan permukiman yang jauh di bawah standar kelayakan, seperti buruknya sanitasi dan akses kesehatan. Kondisi 
ini selain merupakan implikasi dari ketidakpastian pendapatan dari mata pencaharian mereka, juga diakibatkan oleh minimnya lapangan kerja dan rendahnya tingkat pendidikan (Azhari, 1997).

Melihat permasalahan kemiskinan tidak cukup pada gejala-gejala fisik yang tampak dari luar dan satu sektor saja. Persoalan kemiskinan harus ditinjau secara utuh dan multidimensi baik dimensi politik, sosial dan ekonomi.

Berpijak dari kondisi tersebut pemerintah melakukan terobosan kebijakan dalam mengurangi kemiskinan dengan berbagai alternatif solusi pemecahan masalah melalui Program Nasional Pemberdayaan Masyarakat (PNPM) Mandiri. PNPM Mandiri Pedesaan sebagai satu motor penggeraknya dan merupakan program payung (umbrella policy) untuk menjalankan berbagai program pemberdayaan masyarakat (Sujana, 2007).

Tahun ini merupakan tahun ke-8 pelaksanaan PNPM Mandiri sejak dicanangkan pada 2007. Selama delapan tahun tersebut, PNPM Mandiri khususnya PNPM Mandiri Perdesaan di Soppeng telah menunjukkan peran yang signifikan dalam mengasah dan mengasuh masyarakat untuk menjadi berdaya, mandiri dan selanjutnya diharapkan menjadi madani yang ditandai dengan kemampuannya bermitra secara sejajar dengan lembaga lainnya dalam melaksanakan fungsi pemberdayaan masyarakat dalam aspek ekonomi, sosial dan kultural. (www.pnpm-mandiri.org, 2010).

PNPM Mandiri Pedesaan dilaksanakan dengan tujuan mencapai keberlanjutan perbaikan kesejahteraan masyarakat miskin melalui proses pemberdayaan masyarakat yang dilaksanakan dengan menerapkan pendekatan pengokohan kelembagaan masyarakat di tingkat basis yakni Badan Keswadayaan Masyarakat (BKM) yang diharapkan mampu menjadi wadah perjuangan kaum miskin dalam menyuarakan aspirasi dan kebutuhan mereka, sekaligus menjadi lokomotif upaya penanggulangan kemiskinan yang dijalankan oleh masyarakat secara mandiri dan berkelanjutan. (www.pnpm-mandiri.org, 2005).

Pelaksanaan PNPM Mandiri Pedesaan sejak 2007 di Soppeng telah mendorong terjadinya tranformasi sosial dari masyarakat tidak berdaya menjadi masyarakat berdaya, mandiri dan akhirnya madani. Intervensi yang dilakukan dalam mendorong transformasi tersebut selain program regular seperti program penanggulangan kemiskinan juga dilakukan melalui program tambahan di antaranya Peningkatan Penghidupan Masyarakat Berbasis Komunitas (PPMK) dan program Penataan Lingkungan Berbasis Komunitas (PLBK).

Kedua program tersebut merupakan komponen PNPM Mandiri Pedesaan, yang difokuskan pada peningkatan mata pencaharian bagi warga miskin yang terhimpun dalam KSM (Kelompok Swadaya Masyarakat) dan terfokus pada penataan lingkungan permukiman yang sehat. Program ini merupakan kelanjutan intervensi PNPM Mandiri Pedesaan dari tahap berdaya ke tahap mandiri (Halim, 2011).

Program PLBK bertujuan meningkatkan pendapatan masyarakat miskin secara berkesinambungan yang bertumpu pada pengembangan mata pencahariannya melalui: pertama, peningkatan kapasitas keluarga miskin dalam kegiatan ekonomi produktif; kedua, peningkatan kapasitas kelembagaan KSM, dan ketiga, peningkatan pelayanan keuangan mikro untuk masyarakat miskin.

Program Nasional Pemberdayaan Masyarakat Mandiri (PNPM Mandiri) merupakan salah satu program pemberdayaan masyarakat yang mendukung PLBK yang wilayah kerja dan target sasarannya adalah masyarakat perdesaan (www.pnpm-mandiri.org, 2010). Program pemberdayaan masyarakat di kabupaten Soppeng ini dapat dikatakan sebagai program pemberdayaan masyarakat terbesar di Sulawesi Selatan, bahkan terbesar di Indonesia. Dalam pelaksanaannya, program ini memprioritaskan kegiatan bidang infrastruktur desa, pengelolaan dana bergulir bagi kelompok, kegiatan pendidikan dan kesehatan bagi 
masyarakat di wilayah perdesaan dan salah satu komponen utamanya adalah PLBK. Program PLBK (Penataan Lingkungan Berbasis Komunitas) ini adalah lanjutan program PNPM mandiri ini.

Sasaran yang ingin dicapai kegiatan PNPM tersebut adalah diharapkan dapat meringankan beban masyarakat miskin serta memberikan bekal pengetahuan dan keterampilan masyarakat agar dapat menghidupi dirinya dan keluarganya. Di samping itu, program PNPM merupakan salah satu wadah yang berfungsi untuk mendidik dan mengembangkan potensi yang dimiliki masyarakat, agar mereka mampu tumbuh dan berkembang sesuai dengan potensi yang dimiliki.

Salah satu cara mengurangi angka kemiskinan di Indonesia, seperti yang dilakukan program-program sebelumnya, adalah dengan memberdayakan masyarakat miskin dengan memberikan bantuan permodalannya. Hal ini memungkinkan masyarakat miskin untuk dapat memulai usaha produktif (usaha mikro) untuk memperoleh dan meningkatkan pendapatan mereka.

Jumlah usaha mikro kecil dan menengah di Kabupaten Soppeng sebanyak 11.522-unit usaha dengan rincian usaha mikro menempati urutan terbesar yaitu sebanyak 8.783-unit usaha. Disamping itu kegiatan di sektor perdagangan memiliki urutan terbesar juga yaitu sebanyak 7.413 dan sisanya adalah di sektor perkebunan baik bekerja sebagai petani, mengelola hasil kebun dan sawah.

Pada umumnya para pedagang dan petani yang diteliti berada di kecamatan Lalabata. Menurut survey awal yang dilakukan oleh Dinas Pendapatan Daerah Kabupaten Soppeng pada tahun 2005 ditemukan fakta bahwa para pedagang mikro merupakan bagian dari masyarakat golongan ekonomi lemah sehingga perlu mendapatkan bantuan terutama dalam hal tersedianya modal yang cukup untuk menjalankan usahanya. Dengan ini PNPM Mandiri melalui Unit Pengelola Keuangannya (UPK) menjalankan program simpan pinjam untuk para pedagang mikro dan petani di daerah setempat.

Selain itu, rendahnya tingkat pendidikan dan kesehatan di Kabupaten Soppeng ini juga mengakibatkan rendahnya sumber daya manusia di Kabupaten Soppeng ini sangat mempengaruhi tingkat kesejahteraan sebuah keluarga (Burhan Zain, 1997).

Mengacu pada identifikasi masalah, dirumuskan masalah penelitian yaitu bagaimana dampak program PLBK (Penataan Lingkungan Berbasis Komunitas) Program Nasional Pemberdayaan Masyarakat (PNPM) melalui Unit Pengelola Keuangannya terhadap tingkat kesehatan dan pendidikan di Kecamatan Lalabata Kabupaten Soppeng Sulawesi Selatan.

Dari hasil penelitian diharapkan dapat mengetahui perkembangan taraf hidup masyarakat miskin yang ada di Kecamatan Lalabata dari Program PLBK. Kemajuan perkembangan taraf hidup ini diukur dengan seberapa banyak masyarakat yang berpendapatan lebih dari $\$ 1$ perharinya. Selain itu dapat diketahui juga dampak program PNPM ini terhadap kondisi masyarakat Kabupaten Soppeng khususnya di Kecamatan Lalabata dilihat dari berapa besar berkurangnya jumlah orang miskin di Kabupaten Soppeng dan seberapa banyak masyarakat yang mampu menyelesaikan pendidikannya sampai tingkat SMA. Dengan demikian dapat diketahui juga sejauh mana keberhasilan program pemerintah tersebut guna mengentaskan kemiskinan di Indonesia khususnya di Kabupaten Soppeng Sulawesi Selatan.

\section{METODE PENELITIAN}

Sesuai dengan sifat masalah, penelitian ini menggunakan metode penelitian gabungan (Mixed Methods) antara metode penelitian kuantitatif dan kualitatif yang dilakukan secara bersamaan, walaupun proporsi dari masingmasing tipe logika tersebut bervariasi. Pendekatan ini dipilih karena ingin mendalami secara detail, intensif dan komprehensif atas 
dampak yang ditimbulkan oleh Program PLBK melalui pembangunan infrastruktur, pembangunan sekolah gratis dan pembangunan rumah sakit bagi masyarakat di Kabupaten Soppeng khususnya di Kecamatan Lalabata.

Pendekatan kualitatif disebut juga sebagai interpretive approach, yaitu pendekatan yang berupaya menganalisis secara sistematis mengenai gejala sosial yang muncul dari penelitian yang dilakukan secara langsung dengan latar belakang lingkungan yang alami. Sedangkn metode kuantitatif akan menguji program simpan pinjam dari Unit Pengelola keuangan PNPM mandiri terhadap peningkatan pendapatan masyarakat khususnya pedagang mikro dan petani di kecamatan Lalabata Soppeng. Oleh karena itu digunakan analisis regresi sederhana.

Secara sistematis rumus dari regresi linier sederhana dapat dituliskan dengan model persamaan sebagai berikut:

Dengan,

$$
Y i=b_{0}+b_{1} X_{1}+b_{2} X_{2}+b_{3} X_{3}+e_{i}
$$

$Y i$ adalah besarnya pinjaman yang masyarakat ambil kepada UPK PNPM

$X_{1}$ adalah tingkat suku bunga yang diberikan UPK

$\mathrm{X}_{2}$ adalah tingkat suku bunga pesaing dalam hal ini rentenir yang menjadi saingan UPK

$\mathrm{X}_{3}$ adalah lama waktu yang diberikan UPK untuk repayment

$0 \mathrm{~b}$ (intersept) dan $1 \mathrm{~b}$ (slope) adalah parameterparameter yang tidak diketahui

ie adalah disturbance error yang berdistribusi normal $\left(0, \mathrm{~s}^{2}\right)$

Teknik pengumpulan data menggunakan kuisioner, observasi dan wawancara kepada responden dan data yang diperoleh merupakan data kuantitatif dan kualitatif. Wawancara dilakukan dengan pihak-pihak yang memahami masalah yang diteliti.

\section{Rancangan Penelitian Kualitatif-Pendekatan Leiden Ethnosystems}

Pendekatan dengan metode kualitatif dalam penelitian ini menggunakan Leiden
Ethnosystem Approach. Dalam pendekatan Ethnosistems dijelaskan bahwa konsep ini membuka perspektif baru pada pembangunan sosial-ekonomi di dunia ketiga, dan konsep ini berangkat dari metodologi yang umumnya digunakan dalam ethnoscience yang berusaha untuk mempelajari sistem lokal, pengetahuan regional, dan praktek dalam konteks yang lebih dinamis pada perkembangan dan perubahan.

Pendekatan kualitatif akan membahas tentang bagaimana perubahan taraf hidup masyarakat kecamatan Lalabata Kabupaten Soppeng setelah Program PLBK ini dijalankan, mulai dari pembangunan rumah sakit, sekolah dan biaya pendidikan gratis.

Penggunaan pendekatan Ethnosystems dalam penelitian ini adalah sebagai berikut: (1) Participant's View, yaitu melakukan wawancara dengan masyarakat yang telah merasakan dampak program PLBK ini, sejak belum adanya program pemerintah ini sampai dijalankannya selama beberapa tahun. (2) Historical Dimension, yaitu sejarah bagaimana sampai program pemerintah ini diluncurkan, bagaimana agar masyarakat dapat meningkatkan taraf hidup mereka baik dari segi pendidikan, kesehatan maupun ekonomi, hal ini didapat dari hasil wawancara (PV) dan pengkajian dari penelitianpenelitian terkait. (3) Field of Ethnological Study (FES), FES adalah konsep dasar ketiga dalam pendekatan ethnosystems.

Dalam penelitian ini kajian melalui FES sangat relevan untuk dikaji karena masyarakat di Kabupaten Soppeng adalah masyarakat yang dalam konteks perilaku dan kebiasaan mereka masih menggunakan nilai-nilai kehidupan Bugis-Makassar. Dalam hal ini tokoh masyarakat yang menjadi kepala desa sebagai informannya.

\section{Rancangan Penelitian Kuantitatif}

Pusat pada penelitian kuantitatif adalah proses pengukuran karena memberikan link yang mendasar antara pengamatan empiris dan hubungan kuantitatif dari penjabaran matematis. Aplikasi yang dilakukan secara 
bersamaan antara metodologi kuantitatif dan kualitatif adalah metode penelitian campuran atau metode penelitian kombinasi (Ambaretnani, 2012).

\section{Uji F (Regresi)}

Pengujian ini bertujuan untuk menguji signifikasi pengaruh variabel bebas yaitu dampak program PLBK melalui Unit Pengelola Keuangan PNPM Mandiri $(X)$ terhadap variabel terikat, yakni Peningkatan perekonomian dan kesejahteraan (Y). Langkah-langkah yang dilakukan untuk pengujian hipotesis yaitu:

Perumusan hipotesis statistik

1. H0: $\beta 1=\beta 2=\beta 3=\beta 4=0$, artinya Dampak Program PLBK melalui Unit Pengelola Keuangannya tidak berpengaruh secara terhadap peningkatan perekonomian dan kesejahteraan masyarakat di Kecamatan Lalabata Kabupaten Soppeng.

HI: Minimal salah satu $\beta \mathrm{i} \neq 0$, artinya dampak program PLBK melalui Unit Pengelola Keuangannya berpengaruh terhadap peningkatan perekonomian dan kesejahteraan masyarakat di Kecamatan Lalabata Kabupaten Soppeng

2. Penentuan taraf nyata dan daerah kritis Taraf nyata yang digunakan sebesar 5\% ( $\alpha=$ $5 \%$ ). Derajat bebas pembilang adalah V1 = k1, dan derajat bebas penyebut adalah V $2=$ (n-k), dimana $\mathrm{n}=$ jumlah pengamatan dan $\mathrm{k}$ = jumlah variabel, untuk menentukan nilai F-tabel.

3. Menentukan nilai F-hitung

Besarnya nilai F-hitung diperoleh dari hasil regresi dengan program SPSS

4. Kriteria Pengujian

Nilai F $\neg$ hitung dibandingkan dengan Ftabel, dengan kriteria sebagai berikut:

H0 diterima jika F-hitung $\leq$ F-tabel, artinya dampak program PLBK melalui Unit Pengelola Keuangannya tidak berpengaruh terhadap peningkatan perekonomian dan kesejahteraan masyarakat di Kecamatan Lalabata Kabupaten Soppeng.
H0 ditolak jika F-hitung > F-tabel, artinya dampak program PLBK melalui Unit Pengelola Keuangannya berpengaruh terhadap peningkatan perekonomian dan kesejahteraan masyarakat di Kecamatan Lalabata Kabupaten Soppeng.

\section{Variabel Penelitian}

Penelitian tentang dampak program PLBK pada PNPM di Kecamatan Lalabata Kabupaten Soppeng menggunakan beberapa variabel penelitian, yaitu variabel dependen dan independen.

Variabel dependen yaitu besarnya dana yang diberikan Unit Pengelola Keuangan PLBK PNPM kepada Masyarakat $\left(Y_{1}\right)$, sedangkan variabel independennya tingkat suku bunga yang diberikan Unit Pengelola Keuangan PNPM Mandiri $\left(X_{1}\right)$ tingkat suku bunga pesaing UPK PNPM Mandiri, dalam hal ini rentenir menjadi pesaing $\left(\mathrm{X}_{2}\right)$ dan lama waktu repayment yang diberikan UPK $\left(\mathrm{X}_{3}\right)$. Pelaksanaan evaluasi pada PNPM yang dimaksudkan dalam penelitian ini adalah serangkaian aktivitas untuk menentukan kualitas pelaksanaan pengelolaan program dalam suatu organisasi, dengan cara membandingkan hasil-hasil yang dikehendaki serta merumuskan hasil kerja (performance) organisasi dalam mencapai tujuan. Tahapan pelaksanaan evaluasi tersebut meliputi (a) Perencanaan program yaitu suatu aktivitas pengambilan keputusan yang dilakukan secara sadar, terorganisasi, dan terus menerus dilakukan untuk memilih alternatif yang terbaik dari sejumlah alternatif tindakan guna mencapai tujuan atau sasaran (b) Pelaksanaan program adalah proses kegiatan yang melibatkan semua sumber daya manusia, dana dan sarana sesuai dengan pedoman dan petunjuk, waktu dan tempat yang telah ditetapkan (c) Tindak lanjut adalah proses pengembangan yang dilakukan terhadap hasil masing-masing komponen atau hubungan timbal balik antara komponen yang satu dengan yang lain, sehingga dapat ditemukan 
pemikiran atau gagasan untuk mengembangkan program selanjutnya.

\section{Populasi dan Sampel}

Populasi dalam penelitian ini adalah kepala keluarga di Kecamatan Lalabata Kabupaten Soppeng yang berjumlah 256 kepala keluarga yang mendapatkan PLBK. Kecamatan Lalabata dipilih sebagai lokasi penelitian, karena Kecamatan ini memiliki tingkat repayment UPK terbaik yang sudah cukup baik dan kecamatan Lalabata merupakan kecamatan percontohan menjadi objek dari penelitian ini ditetapkan dengan menggunakan teknik Random Sampling. Untuk menentukan ukuran sampel (sample size) minimal digunakan rumus Nazir (1998) sebagai berikut:

Dimana:

$$
\mathrm{n} \geq \frac{N}{N d^{2}+1}
$$

$$
\begin{array}{ll}
\mathrm{n} & =\text { Jumlah sampel } \\
\mathrm{N} & =\text { Jumlah populasi } \\
\mathrm{d} & =\text { Presisi (bound of error) yang diinginkan }
\end{array}
$$
penerima PLBK, sedangkan sampel yang

Berpedoman pada penelitian di bidang ilmu sosial, maka presisi (bound of error) yang digunakan dalam penelitian ini ditetapkan sebesar $10 \%$ atau 0,10 sehingga ukuran sampel dapat dihitung sebagai berikut:

$$
\mathrm{n} \geq \frac{256}{256(0,1)^{2}+1}=\frac{256}{2.6}=98.461
$$

Dengan demikian ukuran sampel minimal dalam penelitian ini adalah sebanyak 98.46 anggota sampel (dibulatkan menjadi 100 anggota sampel).

\section{HASIL DAN PEMBAHASAN}

\section{Karakteristik Responden Masyarakat yang Mengikuti Program PLBK}

Dalam penelitian ini karakteristik responden terbagi atas pendidikan, jenis pekerjaan, dan besarnya pinjaman di Unit Pengelola Keuangan (UPK) PNPM Mandiri.

Pendidikan Terakhir Masyarakat yang Mengikuti Program PLBK

Tabel 1. Data Tingkat Pendidikan Peserta PLBK

\begin{tabular}{llrr}
\hline No & Pendidikan & Jumlah & Persentase \\
\hline 1 & Tidak tamat SD & 22 & $22 \%$ \\
\hline 2 & SD & 51 & $51 \%$ \\
\hline 3 & SMP & 18 & $18 \%$ \\
\hline 4 & SMA/SMK & 9 & $9 \%$ \\
\hline Jumlah & & 100 & $100 \%$ \\
\hline & Sumber: data diolah & &
\end{tabular}

Dapat dilihat pada tabel 1 bahwa sebagian besar masyarakat yang mengikuti program PLBK memiliki tingkat pendidikan SD yaitu sebanyak 51 persen selebihnya pada tingkat pendidikan SMP (18 \%), SLTA (9 \%), dan tidak tamat SD (22 \%). Masyarakat yang hanya lulus dari sekolah dasar banyak mengikuti program PLBK ini karena mereka merupakan target utama dari program PLBK. Lebih dari setengah dari masyarakat yang mengikuti program PLBK ini hanya mampu menyelesaikan pendidikan sampai sekolah dasar saja karena terbentur biaya untuk melanjutkan ke jenjang yang lebih

tinggi. Sedangkan masyarakat yang tidak tamat SD sekalipun karena memang tidak ada biaya untuk sekolah ataupun tidak ingin bersekolah, mereka juga menjadi target PLBK agar kelak anak-anak mereka dapat merasakan pendidikan wajib 12 tahun seperti visi dan misi dari PNPM Mandiri. Di samping itu, minoritas masyarakat yang mengikuti program PLBK baik yang lulusan sekolah menengah pertama maupun yang mampu menyelesaikan sampai tingkat sekolah menengah atas ataupun kejuruan, mereka mengikuti program pemerintah ini dengan harapan mampu memperbaiki taraf hidup mereka melalui program-program yang dilaksanakan oleh PNPM Mandiri ini. 
Tabel 2. Data Jenis Pekerjaan Responden yang Mengikuti PLBK

\begin{tabular}{clcc}
\hline No & Jenis Pekerjaan & Jumlah & Persentase \\
\hline 1 & Petani & 56 & $56 \%$ \\
\hline 2 & Pedagang kelontong & 14 & $14 \%$ \\
\hline 3 & Buruh harian & 6 & $6 \%$ \\
\hline 4 & Berkebun & 24 & $24 \%$ \\
\hline Jumlah & & 100 & $100 \%$ \\
\hline
\end{tabular}

Sumber: data diolah

Dapat dilihat dari tabel 2 bahwa sebagian besar masyarakat yang mengikuti program PLBK bekerja sebagai petani, yaitu sebanyak 56 persen bekerja dengan berkebun $(24 \%)$ menjadi pedagang kelontongan (14\%) dan bekerja sebagai buruh harian (6\%). Mayoritas masyarakat yang mengikuti program PLBK berprofesi sebagai petani.

\section{Besarnya Pinjaman Masyarakat di UPK}

Dapat dilihat dari tabel 3 bahwa sebagian besar masyarakat mengambil pinjaman bantuan modal usaha di Unit Pengelola Keuangan (UPK) sebesar 5-10 juta sebanyak $70 \%$, selebihnya $17 \%$ mengambil pinjaman sebanyak 2-5 juta, 10\%

masyarakat mengambil pinjaman dibawah 2 juta dan hanya 3\% yang mengambil diatas 10 juta rupiah. Sebagian besar masyarakat yang mengikuti program PLBK ini mengambil pinjaman modal usaha sebanyak 5-10 juta rupiah, kebanyakan dari mereka adalah para petani yang ingin meminjam modal usaha untuk membeli pupuk sebelum musim tanam yag baru, biasanya setiap 4 bulan sekali mereka pergi ke Unit Pengelola Keuangan (UPK) PNPM Mandiri untuk mengajukan kredit mikro tersebut. Sedangkan masyarakat lain yang meminjam modal usaha antara 2-5 juta rupiah adalah mereka yang sehari-harinya berjualan ataupun berdagang barang-barang kebutuhan sehari-hari.

Tabel 3. Besarnya Pinjaman Masyarakat kepada UPK

\begin{tabular}{llcc}
\hline No & Besarnya Pinjaman $(\mathrm{Rp})$ & Jumlah & Persentase \\
\hline 1 & $<2$ juta & 10 & $10 \%$ \\
\hline 2 & $2-5$ juta & 17 & $17 \%$ \\
\hline 3 & $5-10$ juta & 70 & $70 \%$ \\
\hline 4 & 10 juta keatas & 3 & $3 \%$ \\
\hline Jumlah & & 100 & $100 \%$
\end{tabular}

Sumber: data diolah

\section{Analisis Kualitatif Dampak Program PLBK terhadap Perilaku dan Kesejahteraan Masyarakat di Kabupaten Soppeng.}

\section{Pandangan Masyarakat Terhadap Program PLBK}

Saat pertama kali pemerintah ingin menjadikan Kabupaten Soppeng sebagai daerah sasaran pengentasan kemiskinan melalui program PLBK, masyarakat sangat antusias dan menerima dengan baik bantuan dari pemerintah itu tersebut. Penduduk setempat juga menunjukkan itikad baik mereka dengan rela melepas tanah mereka dengan harga murah guna dibangun sekolah maupun rumah sakit oleh pemerintah, di samping itu pelaksanaan semua pembangunan infrastruktur melibatkan seluruh lapisan masyarakat menjadikan program PLBK dari pemerintah melalui PNPM Mandiri ini terkesan dari rakyat dan untuk rakyat pula, sehingga program ini sukses berjalan selama 7 tahun sejak pertama kali digulirkan sampai sekarang ini. Selain itu pemerintah daerah juga berperan penting dalam peluncuran program ini. Kapasitas Pemda dan masyarakat yang mampu menjalin kemitraan sinergis dalam penataan lingkungan permukiman itulah yang diharapkan benar- 
benar mampu mewujudkan visi dan misi program ini, yaitu mampu mengentaskan kemiskinan di Kabupaten Soppeng, khususnya di Kecamatan Lalabata. Masalah kemiskinan di Indonesia mendorong pemerintah untuk merombak dan menyesuaikan kembali kebijakan ekonomi dan sistem pemerintahan ke otonomi daerah. Dengan ini tanggung jawab pengentasan kemiskinan berada di tangan pemerintah Sulawesi Selatan dan pemerintah Kabupaten Soppeng. Hal pertama yang dilakukan pemerintah kepada masyarakatnya yaitu melakukan berbagai upaya dan terobosan untuk mengimplementasikan berbagai program pengentasan kemiskinan berbasiskan komunitas masyarakat yang mampu meningkatkan kesejahteraan dan memperluas kesempatan kerja sehingga angka penduduk miskin di Kecamatan Lalabata berkurang secara simultan.

Di satu sisi masyarakat telah merasakan dampak dari program pemerintah ini yang telah meningkatkan kondisi ekonomi mereka, namun di satu sisi program ini juga menciptakan ketergantungan bagi masyarakat. Padahal menurut salah satu pelaksana PLBK yang ditemui di di lokasi penelitian, pada hakikatnya program ini dirancang untuk memandirikan masyarakat.

Upaya pemerintah Soppeng untuk menekan angka kemiskinan telah menampakkan hasil hingga angka kemiskinan di tahun 2011 menurun hingga 21,28\% sejak program ini pertama dilaksanakan pada tahun 2007. Penurunan angka kemiskinan di Kecamatan Lalabata diasumsikan sebagai pengaruh dari program PLBK yang dilaksanakan selama ini yang dititikberatkan pada program pemberdayaan masyarakat. Pendekatan ekonomi diarahkan untuk meningkatkan pendapatan keluarga, sehingga diharapkan masyarakat miskin mampu memenuhi kebutuhan primer dan sekunder sekaligus meningkatkan kesejahteraannya. Sedangkan pendekatan melalui pendidikan dan kesehatan juga sangat penting untuk masyarakat karena untuk pengukuran tingkat perubahan kesejahteraan masyarakat tidak hanya dilihat dari berapa besar kenaikan pendapatan keluarga mereka tapi harus juga dilihat berapa besar perubahan tingkat pendidikan dan tingkat kesehatan di tiap keluarga di Kecamatan Lalabata tersebut. Sejak krisis ekonomi melanda Indonesia di tahun 1998 baru kali ini para masyarakat miskin merasakan perhatian yang serius dari pemerintah, sebelumnya hanya penyuluhan-penyuluhan dan pelatihan saja tanpa adanya tindakan nyata atau tindakan fisik yang dilakukan oleh pemerintah. Oleh karena itu melalui program PLBK dari Program Nasional Pemberdayaan Masyarakat Mandiri ini masyarakat menaruh harapan yang besar untuk meningkatkan tingkat kesejahteraan mereka baik dari segi ekonomi, pendidikan maupun kesehatan mereka.

\section{Pola Pikir Masyarakat Tentang Peminjaman Modal Usaha}

Sejak dulu masyarakat pedesaan hanya mengandalkan pinjaman dari rentenir ataupun modal mereka sendiri yang sangat terbatas, pinjaman dari rentenir atau masyarakat setempat menyebutnya dengan nama Painreng. Rentenir mengharuskan mereka membayar bunga yang cukup tinggi. Tetapi karena prosesnya lebih mudah, mereka lebih disukai masyarakat setempat. Alasannya hanya satu, yaitu mudah. Alasan lainnya kalaupun ada yang biasa meminjam di bank setempat, mereka harus membayar tepat waktu, jika tidak mereka akan terkena denda yang semakin lama dendanya juga semakin besar. Oleh sebab itu masyarakat setempat jera jika berurusan mengenai pinjaman uang.

Selain itu peranan Bank setempat kurang maksimal guna menyalurkan kredit ke masyarakat karena prosesnya yang terbilang cukup rumit seperti yang tertera pada prosedur pengajuan kredit di salah satu bank setempat, yaitu: (a) KTP (Kartu Tanda Penduduk), terkadang dapat juga menggunakan SIM (Surat 
Izin Mengemudi) dan Paspor, juga KTP suami/ isteri. (b) Slip gaji terakhir bagi yang bekerja sebagai karyawan/pegawai. (c) Rekening tabungan 3 bulan terakhir, dengan memperlihatkan sisa uang yang ada di rekening tabungan cukup untuk membayar angsuran bulanan. Yang paling penting adalah rekening transfer gaji dan tunjangan. (d) Kartu Keluarga. (e) Surat Nikah bagi yang telah berkeluarga. (f) Pas foto terakhir asli 3 bulan terakhir. (g) Surat Keterangan Penghasilan dari tempat bekerja.

Sebagian besar masyarakat tidak mampu memenuhi persyaratan untuk peminjaman di bank, dengan latar belakang pendidikan yang rendah, masyarakat kurang mengetahui konsekuensi dari peminjaman di bank. Seperti yang dialami oleh beberapa masyarakat yang terlambat membayar cicilan di bank, keterlambatan 1 hari sudah dikenakan denda, sedangkan penghasilan mereka tergantung dari mata pencarian mereka yang tidak setiap bulan mendapatkan uang. Oleh karena itu sebelum Unit Pengelola Keuangan dari program PLBK PNPM ini ada, sebelumnya mereka meminjam modal kepada para Painreng. Sistem peminjaman modal di painreng ini cukup mudah, mereka cukup datang beserta penjamin dan langsung tanda tangan saja di atas materai dengan jumlah total pengembalian sejumlah uang yang painreng inginkan. Uang pinjaman pun langsung cair saat itu juga, tetapi bunga yang diberikan painreng ini sangat tinggi. Mereka yang meminjam 5 juta rupiah harus mengembalikan 2 kali lipat bahkan 3 kali lipat sesuai dengan hasil panen mereka.

Hal di atas membuat UPK hadir untuk memberikan solusi yang terbaik bagi masyarakat dengan lebih mempermudah proses administrasi dan birokrasi peminjaman modal usaha mikro serta memberikan jangka waktu kepada masyarakat yang meminjam sesuai kesanggupan mereka, seperti contohnya para petani yang mampu membayar cicilan setelah mereka panen, jadi di bulan pertama sampai ketiga mereka tidak membayar dulu, tapi setelah mereka panen dan mendapatkan uang dari hasil panen padi mereka baru bisa membayar cicilan pinjaman mereka sebelumnya.

Tabel 4. Perbandingan Sistem Peminjaman Modal Usaha Pada 3 Institusi di Masyarakat Lalabata

\begin{tabular}{|c|c|c|}
\hline Painreng (rentenir) & $\begin{array}{c}\text { Unit Pengelola Keuangan (UPK) } \\
\text { PNPM Mandiri }\end{array}$ & Bank Konvensional setempat \\
\hline $\begin{array}{l}\text { Cara peminjaman cukup mudah } \\
\text { dan tidak berbelit-belit. Cukup } \\
\text { membawa diri dan penjamin } \\
\text { (keluarga yang dipercaya) }\end{array}$ & $\begin{array}{l}\text { Cara untuk mengajukan kredit } \\
\text { cukup mudah, cukup fotocopy KTP } \\
\text { dan kartu keluarga. }\end{array}$ & $\begin{array}{l}\text { Harus memiliki berkas-berkas seperti, } \\
\text { KTP, kartu keluarga, laporan keuangan } \\
\text { usaha ataupun surat keterangan } \\
\text { penghasilan dan masih banyak lagi } \\
\text { berkas-berkas administratif yang harus } \\
\text { diisi melalui form bank yang tersedia. }\end{array}$ \\
\hline $\begin{array}{l}\text { Uang yang akan dipinjamkan } \\
\text { lansung cair saat itu juga }\end{array}$ & $\begin{array}{l}\text { Modal usaha yang masyarakat ajukan } \\
\text { akan disetujui hari itu juga dan } \\
\text { pendanaan lansung dimulai } 1-2 \text { hari } \\
\text { setelah pengajuan. }\end{array}$ & $\begin{array}{l}\text { Apabila berkas sudah lengkap maka } \\
\text { petugas bank akan mensurvei sang } \\
\text { peminjam }\end{array}$ \\
\hline $\begin{array}{l}\text { Lamanya pengembalian sesuai } \\
\text { dengan kesepakatan peminjam } \\
\text { dan painreng. }\end{array}$ & $\begin{array}{l}\text { Masyarakat bisa membayar cicilan } \\
\text { atau mengembalikan modal usaha } \\
\text { yang dipinjamkan oleh UPK sesuai } \\
\text { kesanggupan (waktu yang diberikan } \\
\text { bervariasi sesuai mata pencarian sang } \\
\text { peminjam) }\end{array}$ & $\begin{array}{l}\text { Masyarakat yang telah diberikan kredit } \\
\text { harus membayar cicilan tiap bulan dan } \\
\text { harus tepat waktu, apabila terlambat } \\
\text { akan dikenakan denda }\end{array}$ \\
\hline $\begin{array}{l}\text { Besarnya bunga diberikan tidak } \\
\text { menggunakan persentase tapi } \\
\text { sudah disepakati berapa } \\
\text { pengembalian dari modal yang } \\
\text { dipinjam. Misalnya orang } \\
\text { tersebut meminjam modal } 10 \text { juta }\end{array}$ & $\begin{array}{l}\text { Suku bunga yang diberikan UPK } \\
\text { PNPM Mandiri sesuai dengan } \\
\text { ketentuan pemerintah dalam } \\
\text { memberikan suku bunga kredit mikro } \\
2,4 \% \text { perbulan }\end{array}$ & $\begin{array}{l}\text { Suku bunga efektif maksimal } 26 \% \\
\text { pertahun }\end{array}$ \\
\hline
\end{tabular}




\begin{tabular}{|c|c|c|}
\hline Painreng (rentenir) & $\begin{array}{l}\text { Unit Pengelola Keuangan (UPK) } \\
\text { PNPM Mandiri }\end{array}$ & Bank Konvensional setempat \\
\hline $\begin{array}{l}\text { Rupiah dan Tahun depan harus } \\
\text { mengembalikan sebesar } 20 \text { juta } \\
\text { Rupiah }\end{array}$ & & \\
\hline $\begin{array}{l}\text { Painreng sudah seperti saudara } \\
\text { saat } \begin{array}{l}\text { masyarakat ingin } \\
\text { mengajukan pinjaman modal }\end{array}\end{array}$ & $\begin{array}{l}\text { Pelayanan petugas UPK lebih } \\
\text { kekeluargan (memakai bahasa daerah } \\
\text { setempat) }\end{array}$ & $\begin{array}{l}\text { Petugas bank terlalu formal terhadap } \\
\text { para masyarakat yang mengajukan } \\
\text { pinjaman }\end{array}$ \\
\hline
\end{tabular}

Analisis Kuantitatif Dampak Program PLBK

Melalui Unit Pengelola Keuangan PNPM

Mandiri Terhadap Peningkatan Tingkat

Perekonomian dan Kesejahteraan Masyarakat di Kecamatan Lalabata Kabupaten Soppeng.

\section{Hasil Uji Regresi}

Untuk menguji hipotesis yang diajukan, dilakukan pengujian secara kuantitatif guna

menghitung apakah terdapat pengaruh program Program PLBK melalui Unit Pengelola Keuangan (UPK) terhadap peningkatan tingkat perekonomian dan kesejahteraan masyarakat di Kecamatan Lalabata, Kabupaten Soppeng. Alat analisis yang dilakukan adalah regresi linier berganda.

Tabel 5. Hasil Persamaan Regresi

\begin{tabular}{|c|c|c|c|c|c|}
\hline \multirow[t]{2}{*}{ Variabel } & \multicolumn{2}{|c|}{$\begin{array}{l}\text { Unstandardized } \\
\text { Coefficient }\end{array}$} & \multirow{2}{*}{$\begin{array}{c}\begin{array}{c}\text { Standardized } \\
\text { Coefficient }\end{array} \\
\text { Beta }\end{array}$} & \multirow[t]{2}{*}{$\mathbf{t}$} & \multirow[t]{2}{*}{ Sig } \\
\hline & B & Std Error & & & \\
\hline Constant & 21,776 & 5,054 & & 2,146 & .000 \\
\hline Tingkat suku bunga UPK & $-0,427$ & 0,155 & $-0,208$ & $-1,377$ & 0.005 \\
\hline Tingkat suku bunga pesaing & 0,124 & 0,121 & 0,77 & 1,012 & 0.156 \\
\hline Kemudahan repayment & $-0,278$ & 0,120 & $-0,173$ & -.152 & 0.014 \\
\hline
\end{tabular}

Dependent Variabel: Besarnya pinjaman modal usaha di UPK PNPM Mandiri

Berdasarkan hasil analisis di atas, maka dapat disimpulkan bahwa model regresi penelitian ini adalah:

Y: Peningkatan besarnya jumlah pinjaman modal usaha di UPK PNPM Mandiri

X1: Tingkat suku bunga yang diberikan UPK

X2: Tingkat suku bunga pesaing (BPR setempat dan rentenir)

X3: Kemudahan dalam repayment yang diberikan

\section{Uji Siginifikansi Simultan (Uji F)}

Uji F digunakan untuk mengetahui apakah

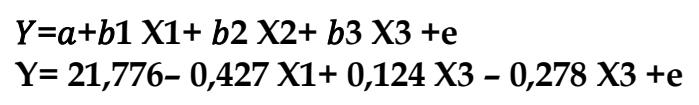

variabel-variabel independen secara simultan berpengaruh signifikan terhadap variabel dependen.

Tabel 7. Tabel Uji F ANOVA ${ }^{a}$

\begin{tabular}{llllll}
\hline Model & Sum of Squares & Df & Mean Squares & F & Sig. \\
\hline Regression & 313,896 & 4 & 78,603 & 3,713 & $.014^{\mathrm{b}}$ \\
Residual & 630,919 & 30 & 20,891 & & \\
Total & 946,223 & 34 & & & \\
\hline
\end{tabular}

a. Dependent Variable: Besarnya Pinjaman Modalc.

Usaha di UPK PNPM Mandiri
Predictors: (Constant), Tingkat Suku Bunga yang diberikan UPK, Tingkat Suku bunga Pesaing (bank dan painreng), jangka waktu Repayment dan kemudahan repayment d. Derajat kepercayaan yang digunakan (a) adalah 0,05 . Berdasarkan hasil perhitungan dengan menggunakan SPSS diperoleh nilai alpha 0,014<0,05, berarti Ho ditolak. Dapat disimpulkan bahwa program PLBK melalui Unit Pengelola Keuangan PNPM Mandiri mempunyai pengaruh yang signifikan terhadap 
peningkatan tingkat perekonomian dan kesejahteraan Masyarakat di Kecamatan Lalabata, Kabupaten Soppeng.

\section{Pengaruh Program PLBK Melalui Unit Pengelola Keuangan PNPM Mandiri terhadap Peningkatan Tingkat Perekonomian dan Kesejahteraan}

Berdasarkan hasil analisis kuantitatif diatas dapat disimpulkan bahwa tingkat suku bunga yang diberikan oleh UPK dan jangka waktu serta kemudahan untuk membayar cicilan (repayment) adalah dua hal yang berpengaruh dalam usaha peningkatan tingkat perekonomian dan kesejahteraan masyarakat di Kecamatan Lalabata.

Tingkat suku bunga yang diberikan UPK PNPM Mandiri sebagai variabel yang sangat berpengaruh di dalam peningkatan perekonomian dan kesejahteraan karena selama ini masyarakat di Kecamatan Lalabata yang sebagian besar berprofesi sebagai petani memiliki kendala modal dan biasanya selain mendapatkan modal usaha dari painreng dengan bunga yang sangat tinggi, mereka hanya mengandalkan modal mereka sendiri yang sangat kecil dan terbatas. Dapat dilihat di tabel 7 setelah adanya Unit pengelola Keuangan PNPM Mandiri untuk menopang keuangan masyarakat guna meningkatkan penghasilan mereka, masyarakat sebanyak $70 \%$ mengajukan pinjaman modal usaha sebesar 5-10 juta dengan bunga $2,4 \%$ perbulan.

Faktor kedua yang juga sangat berpengaruh adalah jangka waktu dan kemudahan masyarakat untuk membayar cicilan (repayment) yang diberikan oleh Unit Pengelola Keuangan PNPM Mandiri. Hal ini dikarenakan sistem pengembalian yang diterapkan oleh UPK sangat membantu masyarakat dan berbeda dengan institusi lainnya dimana masyarakat biasa mendapatkan pinjaman modal usaha seperti di bank setempat dan di painreng.

Dalam upaya untuk meningkatkan perekonomian dan kesejahteraan rakyat, UPK PNPM Mandiri tidak terlepas dari pengaruh bunga bank konvensional dan besarnya tingkat pengembalian yang diberikan oleh painreng yang selama ini menjadi tempat masyarakat untuk mendapatkan modal usaha.

\section{SIMPULAN}

Berdasarkan hasil data yang telah diolah melalui metode kuantitatif dan kualitatif, maka dapat disimpulkan bahwa peningkatan taraf hidup kesejahteraan masyarakat melalui program PLBK dari PNPM mandiri ini sangat berhasil. Pengentasan kemiskinan di Kecamatan Lalabata Kabupaten Soppeng dilakukan dengan beberapa program yaitu: Pertama, melalui jalur pendidikan. Salah satu program dari PLBK ini adalah mendirikan sekolah pemerintah dari SD, SMP dan SMA maupun SMK sehingga masyarakat dapat menyekolahkan anak mereka tanpa dipungut biaya sedikitpun dan mampu meningkatkan tingkat pendidikan masyarakat di Kabupaten Soppeng, khususnya di Kecamatan Lalabata. Sebelumnya sebagian besar masyarakat hanya lulusan SD tetapi setelah adanya program PLBK ini sudah banyak yang mampu menyelesaikan pendidikan sampai SMA maupun SMK. Yang kedua adalah peningkatan kesehatan masyarakat dengan membangun rumah sakit bagi rakyat miskin. Walaupun masyarakat setempat masih sering menggunakan pengobatan tradisional, namun dengan dibangunnya rumah sakit gratis bagi rakyat miskin di Kecamatan Lalabata membuat penduduk setempat beramai-ramai memeriksakan kesehatanya ke rumah sakit tersebut. Mereka mulai mempercayai pengobatan medis dan tidak ragu lagi untuk menggunakan obat dokter. Yang ketiga adalah mendirikan Unit Pengelola Keuangan (UPK) guna membantu masyarakat dalam bidang keuangan khususnya peminjaman kredit usaha mikro dan pemodalan usaha. Dengan adanya UPK ini masyarakat sangat terbantu dengan kemudahan-kemudahan yang diberikan oleh UPK PNPM Mandiri seperti bunga yang rendah dan cara repayment sesuai kemampuan si 
peminjam sehingga mampu meningkatkan tingkat perekonomian mereka.

\section{DAFTAR PUSTAKA}

Ambaretnani, P. 2012. Integrated Medicine for Advanced Partnerships among Traditional Birth Attendants and Community Midwives in the Sunda Region of West Java, Indonesia. Disertation, Leiden University, The Netherlands.

Amin W.T. 1995. Dasar-Dasar Analisis Laporan Keuangan. Cetakan Pertama, Jakarta: PT. Rineka Cipta.

Azhari. 1997. Masyarakat Miskindan Cara Penanggulangannya; Jakarta Universitas Indonesia. Depdagri. 2007. www.depdagri.go.id.

Halim, Yusuf. 2011. Realisasi PNPM perkotaan dan pedesaan . Jakarta.

Nazir. 1998. Metodologi Penelitian Pembangunan Desa. Penerbit Bina Aksara, Jakarta.

Sujana. 2007. PNPM Mandiri. Jakarta.

World Bank. 2011. World Bank's Poverty Estimates Revised. Global issue: http://www.globalissues.org/article/4/povert y-around-the-world. Diunduh tanggal 17 April 2013.

Zain, Burhan. 1997. PNPM Mandiri dan Pelaksanaannya di Sulawesi Selatan. Makassar. 